\title{
Margaret McCartney: We must be smarter about recruitment and retention
}

\author{
Margaret McCartney general practitioner
}

Glasgow

\begin{abstract}
A hundred million pounds is a lot of money. NHS England has pledged to spend as much as this on recruitment agency fees to bring in GPs from abroad. The aim is for 5000 extra GPs. Overseas recruitment will make up a large portion of this new wave of doctors.
\end{abstract}

In the 1960s, general practice in the NHS was saved by Indian and Pakistani doctors, at a time when a third to a half of UK medical graduates were emigrating themselves. ${ }^{1}$ But these doctors were not always well cared for. They often found themselves in the most deprived parts of the country, frequently without much support, discriminated against, and in the least competitive posts (but often the hardest). ${ }^{2}$ How can we be sure that we'll do better now?

We really need to spend money on retaining the GPs we already have, particularly if we're losing them at such a rate (over 1250 fewer GPs in England in March 2017 than in March 2016). ${ }^{3}$

A large group of GPs are retiring early. Many do so because they hate the Quality and Outcomes Framework (QOF), the current GP contractual framework, appraisal, or the pressure of being on call while also consulting. Indemnity fees are soaring and have been cited by GPs as a major reason for early retirement. Surely, the money allocated to overseas recruitment could be used to employ people who have pledged to retire in the next decade.

We really need to spend money on retaining the GPs we already have

We could offer moderated, abbreviated appraisal and a fresh approach to QOF (we've abandoned it in Scotland, and the sky hasn't fallen in). We could offer protected sessions to make working in later life a realistic_even popular-option. Bringing in doctors from abroad will incur other costs including training and orientation: are we sure that we're spending our money wisely?

And some GPs want to return to practice. Huge efforts have been made to streamline this process, but is it working? Over the past couple of years I've watched as an outstandingly sharp, knowledgeable doctor I know wanted to return to general practice after a few years out of the country. She's faced obstacles despite having worked as a GP for several years before she left.

The costs are prohibitive: she had to self fund a trip to the GMC in London for an identification check. She then had to study for and pass a multiple choice exam followed by a simulated surgery (first attempt is free; resits cost $£ 150$ and $£ 850$, refundable at the end of the scheme). After passing the exams, a supervised placement must be found amid the myriad forms. A bursary is payable for this, but doctors have found it slow to appear and not reliable for paying the bills. In the meantime, the GMC fees roll on, and indemnity fees must be paid up front. And practices must apply to be accredited to supervise returning GPs-limiting the doctors' availability and often making them hard to find.

More than a year after trying to start back, the doctor I mentioned still isn't working as a GP. Couldn't some of NHS England's money be spent on sorting out the numerous small bureaucracies that add up to an insurmountable barrier?

Some crises are unavoidable; some have been created through an obsession with process above reasonable judgment. Expecting doctors to come from abroad and sort out our mess, while doctors go to waste here, is senseless.

Competing interests: See www.bmj.com/about-bmj/freelancecontributors/margaret-mccartney.

Provenance and peer review: Commissioned; not externally peer reviewed.

Follow Margaret on Twitter, @mgtmccartney

1 Snow SJ, Jones EL. Immigration and the National Health Service: putting history to the forefront. History and Policy 8 March 2011. www.historyandpolicy.org/policy-papers/ papers/immigration-and-the-national-health-service-putting-history-to-the-forefron.

2 How Asian doctors saved the NHS. BBC News 26 Nov 2003. http://news.bbc.co.uk/1/hi/ health/3239540.stm.

3 NHS Digital. General and personal medical services, England as at 31 March 2017 , experimental statistics. 22 Aug 2017. http://digital.nhs.uk/catalogue/PUB30044.

Published by the BMJ Publishing Group Limited. For permission to use (where not already granted under a licence) please go to http://group.bmj.com/group/rights-licensing/ permissions 
